\title{
GONDOLATOK A BALATON IDŐBEN VÁLTOZÓ VÍZHÁZTARTÁSÁRÓL ÉS VÍZSZINTSZABÁLYOZÁSÁRÓL
}

THOUGHTS ON THE TIME-VARYING WATER BALANCE AND WATER LEVEL CONTROL OF LAKE BALATON

\author{
VARGA GYÖRGYac - JAKUS ÁDÁM ${ }^{\text {bd }}$ \\ aokl. hidrológus, monitoring referens, c. egyetemi docens, Országos Vízügyi Főigazgatóság \\ bokl. környezetkutató, okl. hidrológus, kiemelt műszaki referens, Országos Vízügyi Főigazgatóság \\ cvarga.gyorgy@ovf.hu, d jakus.adam2@ovf.hu
}

\begin{abstract}
Lake Balaton is a shallow lake with an average depth of about $3.5 \mathrm{~m}$. The shallow lakes are extremely sensitive to environmental changes in both quantity and quality. The water management processes of the past two decades have provided many warning signals. Above all, as a result of the increasingly extreme weather conditions, unusual and, in any case, extreme conditions of water management have occurred more frequently and to a greater extent. Lake Balaton is a natural lake, but at the same time it is a widely used holiday lake both nationally and internationally. Today, two solutions seem to be appropriate for sustainability. One is to increase bed storage by raising the level of regulation. The other is the quick and safe drainage of the water above the control level in the lake, and the modernization of the drainage system (Sió-sluice, Sió-riverbed)
\end{abstract}

Keywords: shallow lake, increased sensitivity to environmental changes, water balance, water level control, natural water supply change, regulation level increase, drainage system modernization

\section{Bevezetés}

A Balaton és közvetlen környezete - mint kiemelkedő jelentőségủ nemzeti kincs hosszú ideje áll a szakmai és a szélesebb érdeklődő közvélemény figyelmének homlokterében. A tó vízminőség-romlásának megállítása, javítása céljából az elmúlt mintegy négy évtizedben számos - tudományos kutatási eredményekre támaszkodó - döntés történt a vízminőség-védelem és -szabályozás területén. Az utóbbi két-három évtizedben a korábbiaknál gyakrabban és többet hallottunk a tó vízmennyiségével, vízkészletének változásával, vízállásának alakulásával kapcsolatos kérdésekről, amelyeket alapvetően a tó vízháztartását meghatározó természeti tényezők okoztak. A vízháztartási folyamatok jellemzésére kézenfekvő módszer a tó vízforgalmának megismerése, amely a vízforgalomban szerepet játszó vízháztartási tényezők meghatározását és ennek alapján a vízháztartási mérleg összeállítását jelenti. 


\section{A Balaton hosszú idejú vízszintváltozásai}

A Balaton napjainkig folyamatosan meglevő, egységesen összefüggő vízfelülete 60008000 éve alakulhatott ki, vagyis nemcsak földtani, hanem limnológiai értelemben is igen fiatal képződmény (BENDEFY L. 1968). A tó vízháztartását és vízjárását történelmének első, mintegy hétezer éves időszakában kizárólag természeti körülmények befolyásolták. A régészeti kutatások szerint az ember korán megtelepedett a tóparton és a vízszinti-ingadozásoktól függően változtatta településeinek helyét, de a tó életébe nem avatkozott be (1. ábra).

A Balaton fejlődésének második, máig tartó szakaszát az emberi beavatkozások napjainkig tartó következményei jellemzik. Egyes szerzők szerint az avarok (7-8. század) már a vízeltereléseket, mesterséges elöntéseket védőmüként alkalmazták. Az első valószínüsíthető beavatkozás Galerius császár idején (3. század) történt, bár a Siófoknál épített Galerius-féle zsilip létezéséről megoszlanak a vélemények. A legenda szerint a tatárdúlás hírére a tihanyiak elzárták a tó természetes lefolyását lehetővé tevő fokot, és a megemelkedett vízszint szigetté formálta a Tihanyi-félszigetet.

A 13. századig a partvonal és a vízszint alakulása lényegesen nem tért el a római kori állapottól. A 14. századtól a 17. századig az éghajlati viszonyok változásának hatására a tó szintje megemelkedett és elérhette a természetes hidrológiai egyensúlyt. A vízgyüjtőn nem történt olyan beavatkozás, amely a tó addigi vízháztartási viszonyait

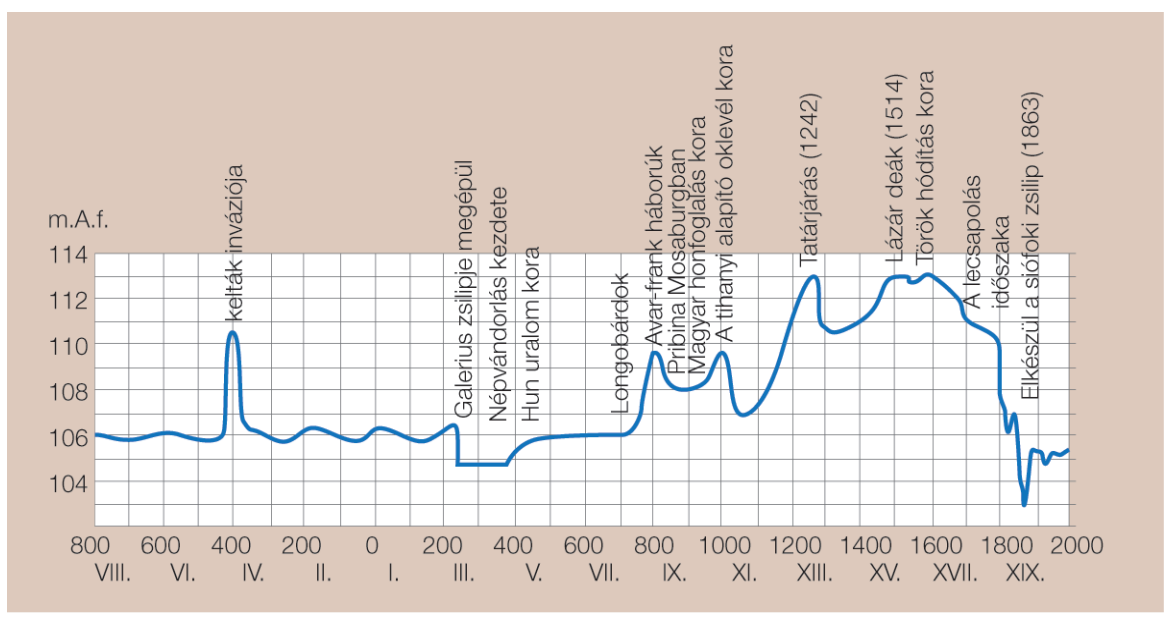

1. ábra. A Balaton tartós vízállásainak görbéje Kr. e. 800-tól napjainkig (BENDEFY L. 1965 nyomán) 
érintette volna. Mintegy 60\%-os lehetett az erdős-cserjés terület aránya, a Zala és a déli parti mellékvizek alsó szakasza mocsaras volt, ami sok vizet párologtatott el. A hozzáfolyás csak mintegy fele volt a mainak, ugyanakkor a párolgás a maihoz volt hasonló. Ennek következtében a tóból lefolyás a 14. század végéig csak időszakosan fordult elö. A 15-17. században bekövetkezett csapadékosabb és hüvösebb időjárás hatására nagyobb hozzáfolyás és kisebb párolgás alakult ki, emelkedett a vízállás és gyakoribbá vált, nőtt a lefolyás.

A 18. század elejétől fokozatosan kezdődtek meg azok az emberi beavatkozások a vízgyüjtőn és a parton, amelyek befolyással voltak a tó vízháztartására és vízjárására. A vízgyüjtőn végrehajtott, nagy területet érintő erdőirtások hatására megváltoztak a lefolyásviszonyok, a melegebbre fordult időjárás következményeként szélsőségesebb lett a csapadékeloszlás, fokozódott az erózió. A tó vízszintingadozása növekedett, szélsőségesebbé vált a vízjárás (MÉszáros E. - Schweitzer F. 2002).

1863-ig a Balaton vízállása a maitól merőben eltérő hidrológiai viszonyok között alakult ki. Ezek összefoglalva a következők voltak:

- a vízgyüjtő terület maitól eltérő növényborítottsága és müvelése;

- a tavat tápláló vízfolyások szabályozatlansága;

- a Kis-Balaton, a Nagyberek és a Tapolcai-öblözet ősállapota (mocsár, csaknem összefüggő vízborítás);

- a Sió-völgy szűkös vízszállító kapacitása, a vízeresztő zsilip hiánya.

A Balaton vízállásai és vízszintingadozásai 1863-tól a Siófoki-zsilip és vízmérce üzembe helyezésétől ismertek. Ezek a vízállások a korábbinál kisebb, de még mindig jelentős vízszint-ingadozásokat mutatnak. A Sió-zsilip többszöri átépítése, a Sió-meder vízlevezető-képességének bővítése lehetővé tette a vízszintszabályozás rendjének fokozatos módosítását, amely a szabályozási sáv fokozatos szükítését és emelését jelentette. A szabályozási szintek többször változtak, aminek politikai, gazdasági-társadalmi, müszaki és hidrológiai okai is voltak (2. ábra). 2016-ban a vízszint-szabályozási sávot hatályon kívül helyezték, és a tó szabályozási szintjét 120 cm-ben állapították meg. Ez azt jelenti, hogy a parti és partközeli területek elöntés elleni védelme céljából a $120 \mathrm{~cm}$ feletti vízkészletet a Sió-csatornán levezetik a tóból (BARANYi S. 1980, VirÁg Á. 1997, 2005). 


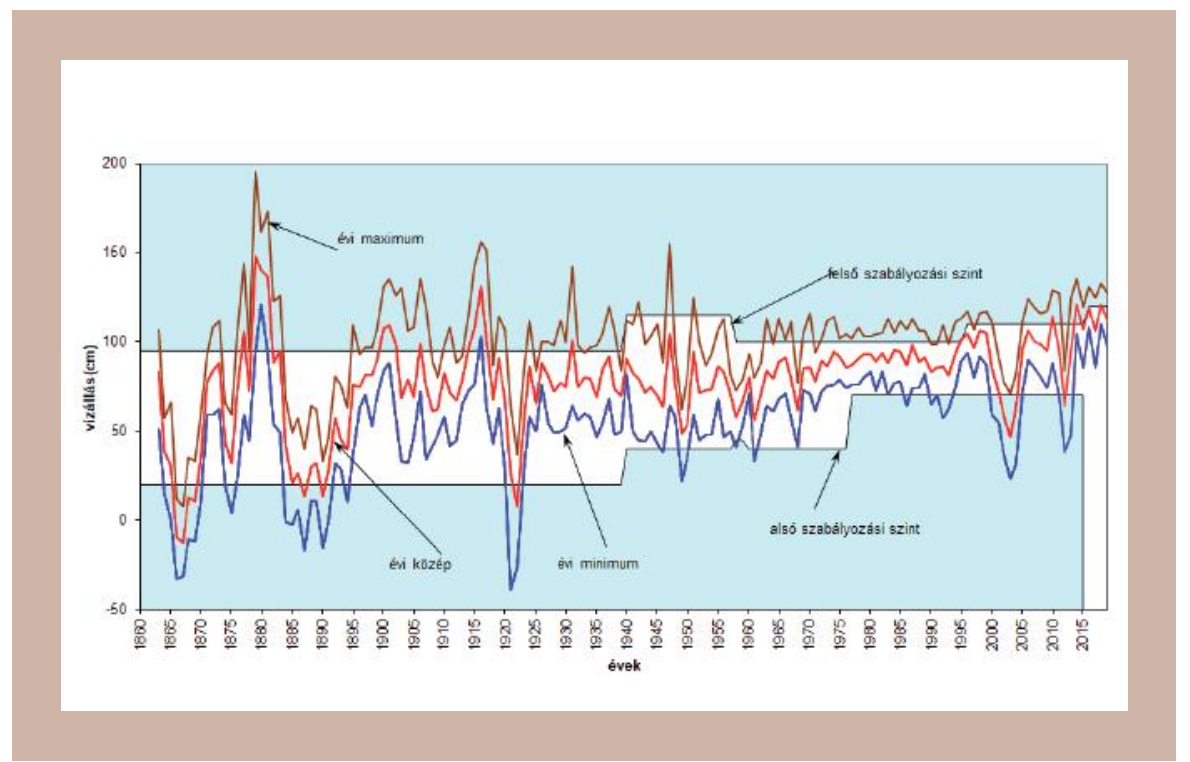

2. ábra. A Balaton évi minimális, átlagos és maximális vizállásai 1863-2019 között (a VITUKI és a KDTVİZIG adatsorai alapján szerk. VARGA GY. - JAKUS Á.)

\section{A Balaton vízháztartását meghatározó tényezők időbeli változásainak jellemzése az 1921 utáni időszakban}

A Balaton vízháztartásának részletes vizsgálatával először Szesztay KáRoly foglalkozott, aki az 1921-1958 közötti évekre készített havi vízháztartási mérlegeket. Öt megelözően csupán a vízháztartás egy-egy tényezőjét (párolgás, természetes vízkészletváltozás) vizsgálták. Az 1863-1920 közötti évekre csak a vízeresztést, a vízállásváltozást és ezek összegeként a vízkészlet természetes változását határozták meg. A vízkészlet változásáról az 1921 előtti időszak adatai pontatlanok, azokat vízháztartási mérlegben nem ellenőrizték. Hasonlóan nem megbízhatók a tó párolgására vonatkozó 1921 előtti adatok sem.

A Balaton vízháztartását az alábbi egyszerủ egyenletekkel írhatjuk le:

$$
\begin{gathered}
\Delta \mathrm{K}=(\mathrm{C}+\mathrm{H})-(\mathrm{P}+\mathrm{L}+\mathrm{Vh}) \\
\Delta \mathrm{K}_{\mathrm{T}}=\mathrm{C}+\mathrm{H}-\mathrm{P}
\end{gathered}
$$


ahol

- C - a tóra hulló csapadék

- H - hozzáfolyás a tóhoz

- P - párolgás a tó felszínéről

- L - lefolyás (vízeresztés) a Sió-csatornán

- Vh - közvetlen vízhasználat a tóból (a tóból kivett és használat után visszavezetett vízmennyiségének különbsége)

- $\Delta \mathrm{K}$ - a tó vízkészlet-változása

- $\Delta \mathrm{K}_{\mathrm{T}}$ - a tó természetes vízkészlet-változása

Mindezek alapján 1921 óta rendelkezünk ellenőrzött, megbízhatónak értékelt vízháztartási mérlegekkel a Balatonra, azaz vízháztartási tényezőnként 99 éves idősorok állnak rendelkezésre.

Az 1. táblázatban közölt adatok szerint sokévi átlagban a Balaton a mindenkori vízszint-szabályozási rendhez viszonyított (szabályozott lefolyással) rendelkezik, aminek mennyisége közelítőleg a tóra hulló átlagos évi csapadékmennyiséggel egyezik meg (BArAnyi S. 1980, VArga Gy. - Jakus Á. - KravinszKaja G. 2019). Sokévi átlagban a hozzáfolyás és a vízmérleg kiadási oldalán legnagyobb súlyú párolgás közelítőleg azonos abszolút értéküek.

\begin{tabular}{|l|r|r|r|r|r|}
\hline Vízháztartási tényező & \multicolumn{2}{|c|}{ Minimum } & \multicolumn{2}{c|}{ Átlag } & \multicolumn{2}{c|}{ Maximum } \\
\hline & (tómm/év) & év(ek) & (tómm/év) & (tómm/év) & 2010 \\
\hline Csapadék & 309 & 2011 & 618 & 929 & 1965 \\
\hline Hozzáfolyás & 236 & 2012 & 848 & 1974 & 1946 \\
\hline Párolgás & 723 & 1970 & 896 & 1073 & 1965 \\
\hline Természetes vízkészletváltozás & -281 & 2012 & +570 & +2031 & 1965 \\
\hline Lefolyás (vízeresztés) & 0 & 2001 & 551 & 1791 & \\
& & 2003 & & & \\
\hline
\end{tabular}




\section{A Balaton-vízgyüjtő és a Balaton egyes hidrológiai és hidrometeorológiai paraméte- reinek hosszú idejü alakulása}

\section{A Balaton-vízgyüjtöre hulló csapadék}

A Balaton-vízgyüjtőre hulló évi csapadék mennyiségének meghatározása 25 csapadékmérő állomás mérési adataiból képzett területi átlag alapján történik. A 3. ábrán szemléltetjük a Balaton-vízgyűjtőre hulló csapadék évi területi átlagértékeit. A teljes időszakra (1921-2019) vonatkozó átlag 684 mm/év, a szélsőértékeket két egymást követő évben (!), a minimumot $(395 \mathrm{~mm})$ 2011-ben, a maximumot $(992 \mathrm{~mm})$ 2010-ben jegyezték fel.

A Balaton vízgyüjtő területére érkező csapadékmennyiség jellemzéséhez a WMO 1983. évi ajánlását alkalmaztuk, ami a meteorológiai paraméterek - évtizedenként továbbléptetett - 30 éves átlagértékeinek alakulása alapján javasolja a hosszú távú változások bemutatását és értékelését. Ennek szemléltetésére állítottuk össze a 2. táblázatot.

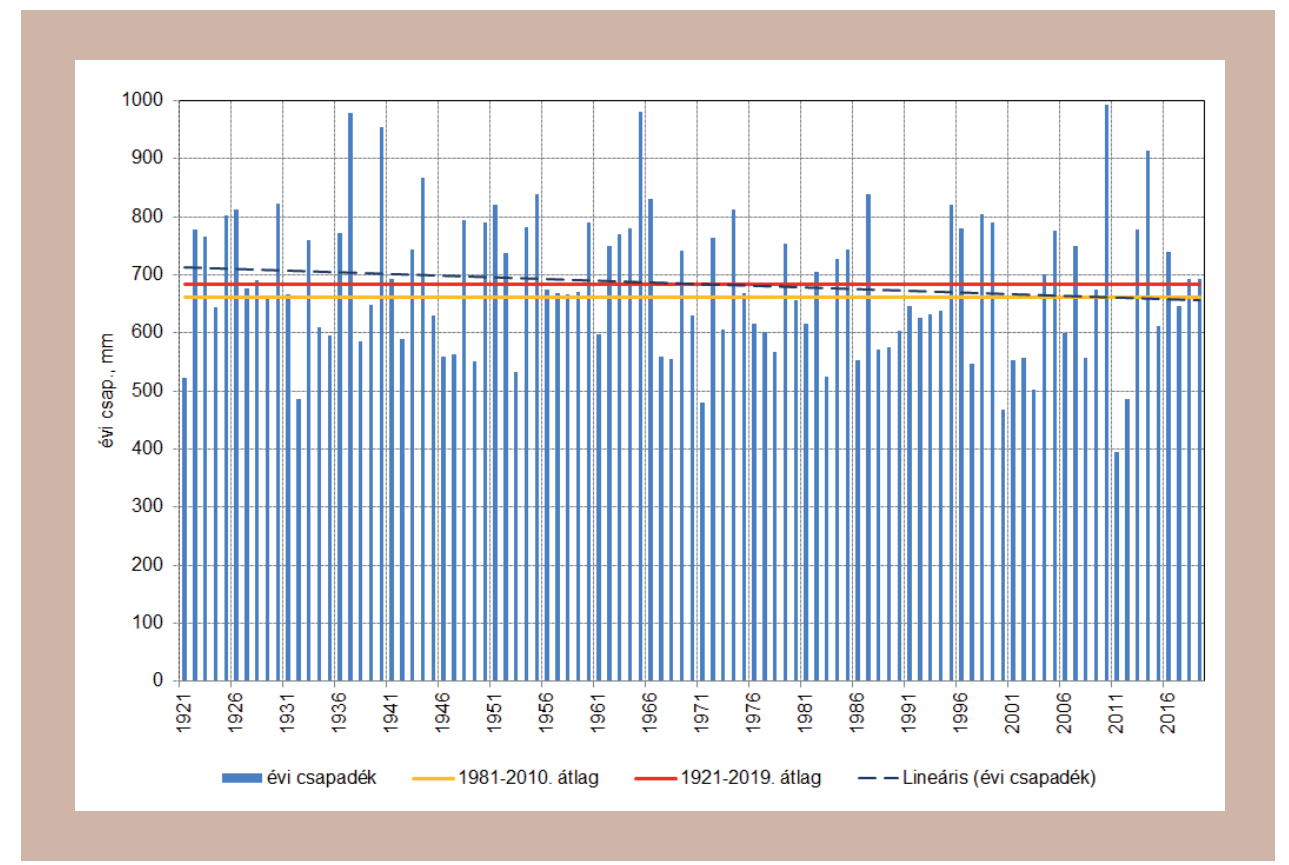

3. ábra. A Balaton-vízgyüjtőre hulló csapadék évi összegei 1921-2019 között (az OMSZ adatsorai alapján szerk. VARGA GY. - JAKUS Á.) 


\begin{tabular}{|l|r|}
\hline Időszak & $\begin{array}{r}\text { Átlagos évi csapadékmennyiség } \\
\text { (mm/év) }\end{array}$ \\
\hline $1921-1950$ & 700 \\
\hline $1931-1960$ & 701 \\
$1941-1970$ & 705 \\
$1951-1980$ & 697 \\
$1961-1990$ & 672 \\
$1971-2000$ & 658 \\
\hline $1981-2010$ & 662 \\
\hline
\end{tabular}

2. táblázat. A Balaton vizgyüjtő területére hulló évi csapadék 30 éves átlagértékei (az OMSZ adatsorai alapján szerk. VARGA GY. - JAKUS Á.)

A 3. ábra szerint az 1960 évek közepétől a korábbi időszakokhoz képest nagyobb számban fordultak elő az átlagosnál szárazabb évek. Ez a jelenség a tó vízgyüjtő területén halmozódó vízhiányt eredményezett, ami - a hozzáfolyás tartós csökkenésével együtt - kedvezőtlenül befolyásolta a tó vízforgalmát, tartós vízkészlet- és vízálláscsökkenést okozott. Külön kiemelésre érdemes a 2000 és 2003 közötti 4 éves időszak. Ekkor a felhalmozódott sokévi átlaghoz viszonyított összegzett csapadékhiány (653 $\mathrm{mm}$ ) megközelítette az egyéves átlagos csapadékmennyiségnek megfelelő értéket. Ebben az időszakban 1921 óta legszélsőségesebb deficites vízháztartási helyzet alakult ki a vízgyüjtő és a tó vízforgalmában.

\section{A léghőmérséklet alakulása a Balaton vízgyüjtö területén}

A vízgyüjtő évi középhőmérsékletének alakulását - területi átlagban - 4 állomás adatainak felhasználásával határoztuk meg az 1951-2019 időszakra. A vízgyüjtő sokévi (1951-2019) átlaga $10,4{ }^{\circ} \mathrm{C}$. A vízgyüjtő éves átlaghőmérsékleteinek idősorát és trendjét a 4. ábra mutatja.

\section{A Pálfai-féle aszályindex alakulása a Balaton vízgyüjtö területén}

A Pálfai-féle évi aszályindexnek (PÁLFAI I. 2004) a Balaton-vízgyüjtőre vonatkozó területi átlagát 6 állomás adatainak felhasználásával határoztuk meg. Az 1931-2019 közötti időszakra vonatkozó idősort az 5. ábrán szemléltetjük. Megállapítható, hogy az 1980-as évek közepe óta a korábbi időszaknál nagyobb gyakorisággal fordultak elő enyhe, mérsékelt vagy jelentékeny aszállyal jellemezhetö évek. 


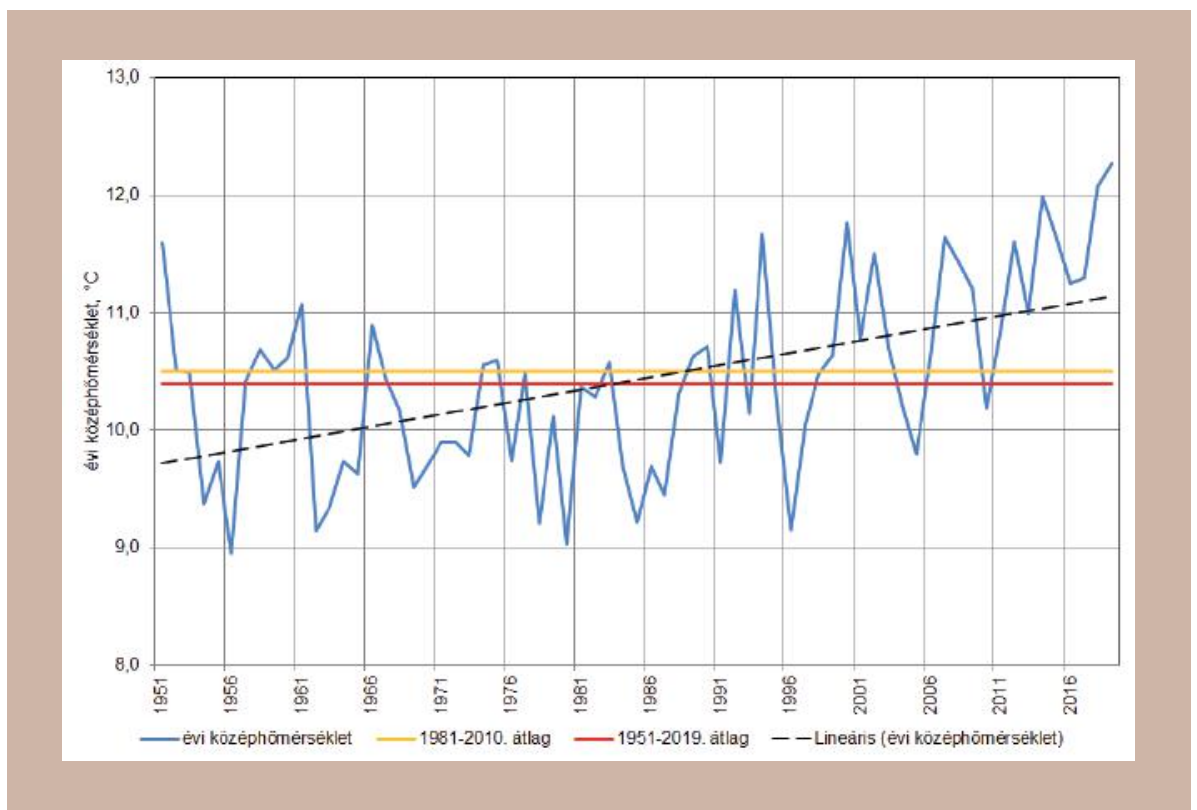

4. ábra. A Balaton-vízgyüjtő éves átlagos léghőmérsékleteinek 1951-2019 közötti idősora (az OMSZ adatsorai alapján szerk. VARGA GY. - JAKUS Á.)

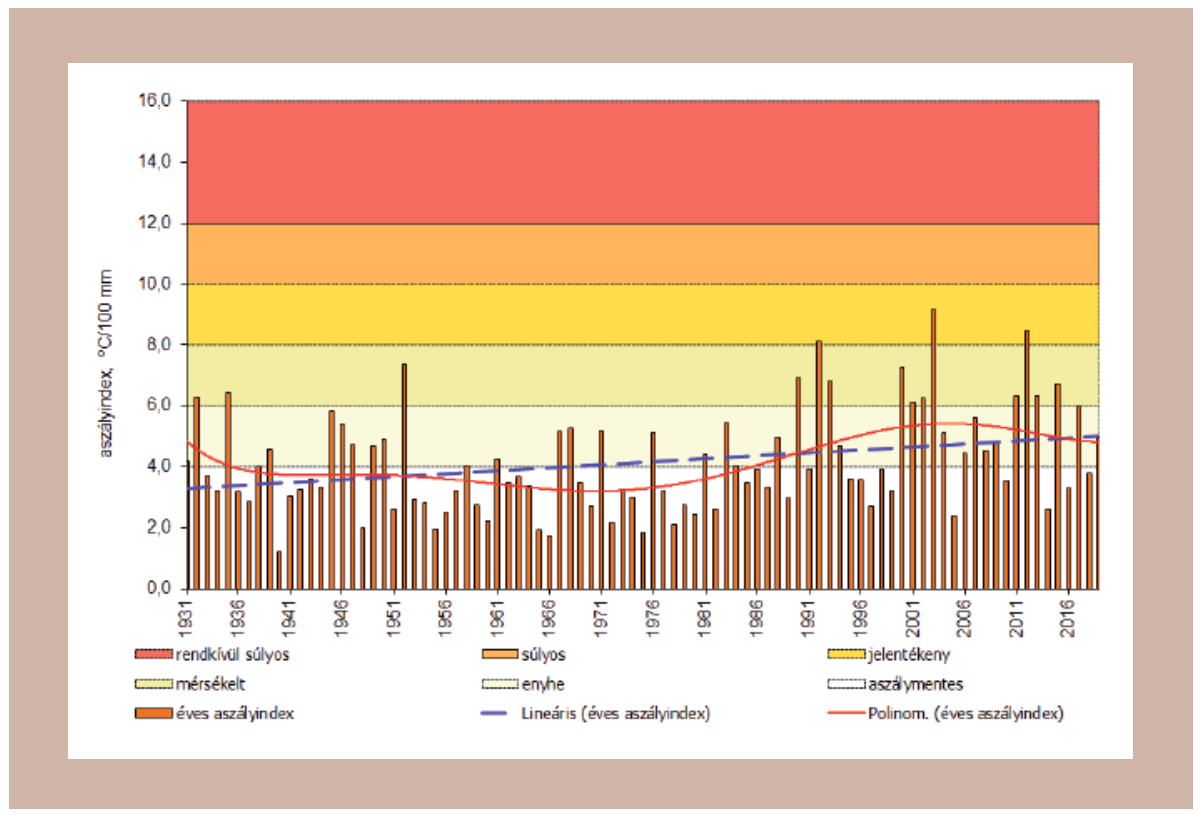

5. ábra. A Pálfai-féle aszályindex évi területi átlaga a Balaton-vízgyüjtön 1931-2019 között (a VITUKI és a KDTVÍZIG adatsorai alapján szerk. VARGA GY. - JAKUS Á.) 


\section{A Balaton természetes vízkészlet-változása}

Egy tó vízháztartásában természetes vízkészlet-változásként a természeti tényezők által meghatározott vízháztartási tényezők (a Balaton esetében a tóra hulló csapadék, a tóhoz történő hozzáfolyás, valamint a vízfelületről történő párolgás) algebrai összegét értjük. Ez az előbbiek szerint számított mutatószám integráltan jellemzi a tó vízháztartásának alakulását. A 6. ábrán szemléltetjük a Balaton évi természetes vízkészlet-változásának idősorát. Szembetűnő az 1970-es évek közepétől jellemző erőteljes csökkenő irányultság, amely feltűnő hasonlóságot mutat a hozzáfolyás ugyanezen időszakban bekövetkezett változásával.

Kiemelendő tény az is, hogy az 1921-1999 közötti időszakban a természetes vízkészlet-változás évi összegének minden évben pozitív volt az előjele. Ez azt jelenti, hogy a tó vízmérlegében a természetes vízbevétel (csapadék + hozzáfolyás) több volt, mint a természetes kiadás (párolgás) értéke. Ezt követően a 2000 és 2019 közötti 20 éves időszakban 7 (!) olyan év fordult elö, amikor a természetes bevétel kisebb volt, mint a természetes kiadás (Kutics L. 2015, KravinszKaja G. 2019).

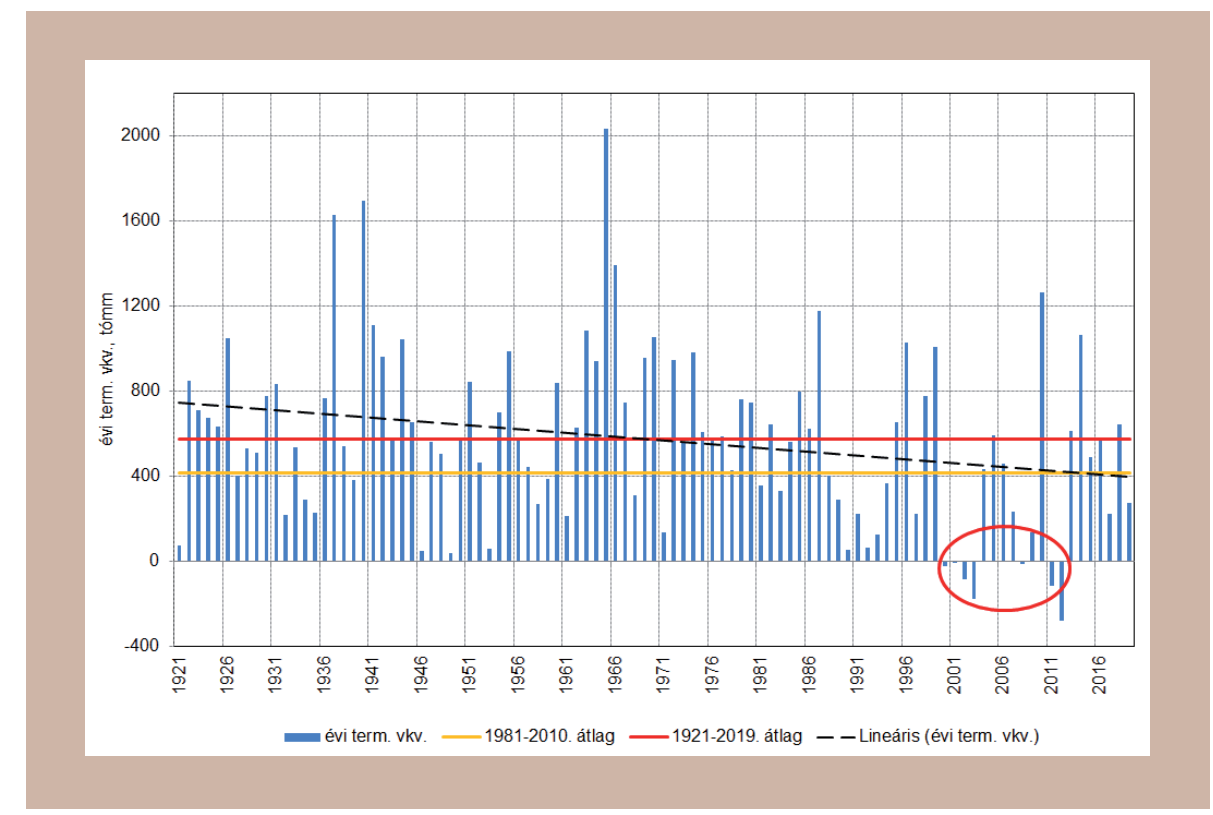

6. ábra. A Balaton évi természetes vízkészlet-változása mm-ben (a VITUKI és a KDTVİZIG adatsorai alapján szerk. VARGA GY. - JAKUS Á.) 
A Balaton természetes vízkészlet-változásának jellemzéséhez is figyelembe vettük a WMO 1983. évi ajánlását, amely a meteorológiai (és hidrológiai) paraméterek - évtizedenként továbbléptetett - 30 éves átlagértékeinek alakulása alapján javasolja a hosszútávú változások bemutatását és értékelését (3. táblázat).

\section{A Balaton (szabályozott) lefolyása}

A Balaton vízszintjének (vízkészletének) operatív szabályozása egyetlen helyen, a siófoki zsilipen történő vízeresztéssel valósulhat meg. A Balatonból történő vízeresztés a tó vízforgalmában a legerőteljesebb emberi beavatkozások közé tartozott, amit az érvényben lévő vízszint-szabályozási rend szerint hajtottak végre. A vízszint-szabályozási szintek többször változtak, aminek alapvetően szakmapolitikai, gazdasági-társadalmi, műszaki és hidrológiai okai voltak (SzLÁviK L. 2005).

1921 óta a legnagyobb többletvíz-készlet levezetésére 1965-ben került sor. A 2000 és 2003 közötti időszakban felhalmozódott vízhiány következtében 2000 májusától 2005 augusztusáig a tóból vízeresztés nem történt (7. ábra).

A szabályozási szint feletti többletvíz-készletek levezetésével végrehajtott vízszint-szabályozásnak természetesen korlátai vannak. A Balaton természetes vízjárásában - a vízforgalmat alapvetően meghatározó hidrometeorológiai és hidrológiai tényezők térben és időben bekövetkező jelentős természetes változékonysága miatt - növekvő számban és időtartamban fordulhatnak elő szélsőséges állapotok. Tekintve, hogy a Balaton átlagos hidrometeorológiai és hidrológiai viszonyok esetén természetes lefolyással rendelkező tó, és az évi lefolyás közelítőleg a tóra hulló évi csapadékmennyiséggel

\begin{tabular}{|l|r|}
\hline Időszak & $\begin{array}{r}\text { Átlagos évi természetes } \\
\text { vízkészlet-változás (mm/év) }\end{array}$ \\
\hline $1921-1950$ & 645 \\
$1931-1960$ & 623 \\
$1941-1970$ & 698 \\
$1951-1980$ & 707 \\
$1961-1990$ & 696 \\
$1971-2000$ & 532 \\
$1981-2010$ & 416 \\
\hline
\end{tabular}

3. táblázat. A Balaton sokévi természetes vizkészlet-változásának átlagértékei (a VITUKI és a KDTVÍZIG adatsorai alapján szerk. VARGA GY. - JAKUS Á.) 


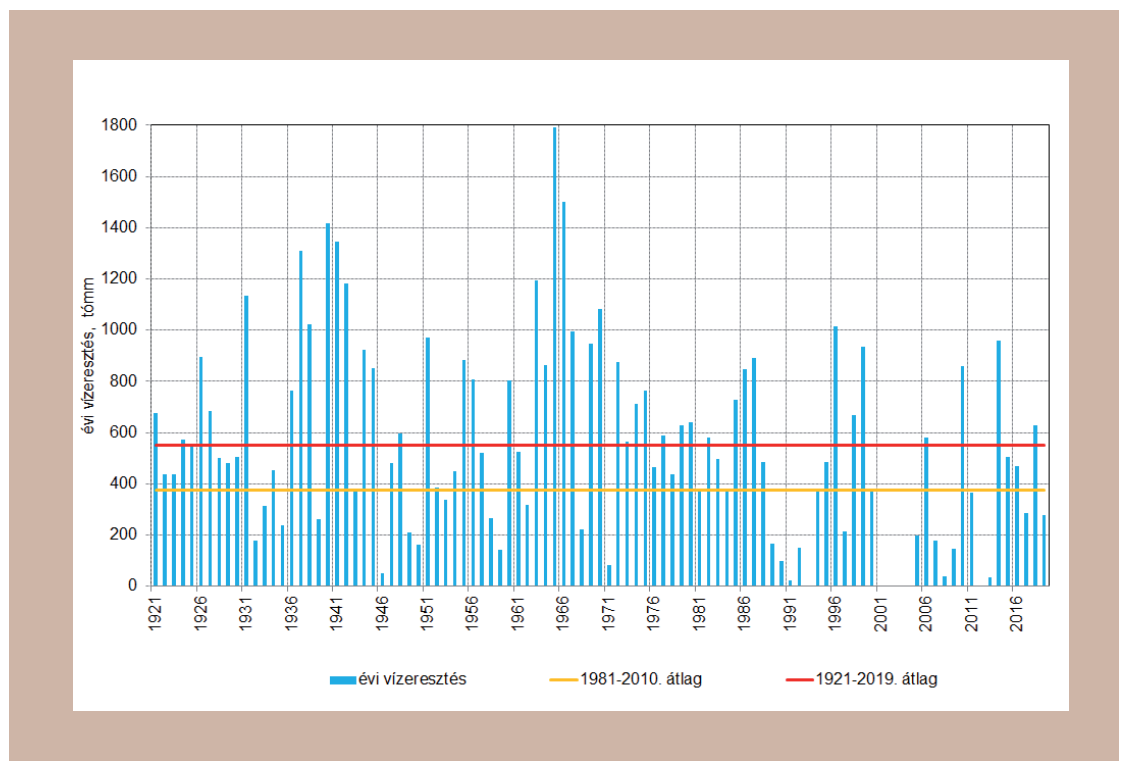

7. ábra. A Balaton évi (szabályozott) lefolyása mm-ben (a VITUKI és a KDTVÍZIG adatsorai alapján szerk. VARGA GY. - JAKUS Á.)

egyezik meg, mindenképpen szélsőséges vízháztartásúnak értékelhetők azok az évek, amikor nem képződött levezethető vízmennyiség a tóban, illetve ha a vízeresztés sokévi átlagát számottevően meghaladó vízmennyiség levezetésére van szükség.

\section{Összegzés, előretekintés}

A mintegy 3,5 mátlagmélységü Balaton jellegzetes sekély tó. Az ilyen tavak mind mennyiségi, mind minőségi vonatkozásban rendkívül érzékenyek a környezeti változásokra. A mennyiségi érzékenység a vízforgalmat meghatározó vízháztartási tényezők változékonyságában nyilvánul meg, amelyek - egyéb, a vízháztartást érintő emberi beavatkozások mellett - együttesen határozzák meg a tó vízállásának mindenkori alakulását. Az elmúlt két évtized vízháztartási folyamatai számos intő jellel szolgáltak. Elsősorban a szélsőségesebbé váló időjárás hatására gyakrabban és nagyobb mértékben fordultak elő szokatlan, mindenképpen szélsőségesnek nevezhető vízháztartási állapotok.

A Balaton természetes tó, ugyanakkor hazai és nemzetközi értelemben is széles körben hasznosított üdülőtó. A fenntarthatóság érdekében, valamint a vízforgalmat meghatározó, térben és időben egyre szélsőségesebbé váló természeti tényezők a tóhasználat szempontjából 
kedvezőtlen hatásainak mérséklése érdekében napjainkban két megoldás látszik célravezetőnek. Az egyik a medertározás növelése, ami a szabályozási szint közelmúltban történt $10 \mathrm{~cm}$-rel (mintegy 60 millió $\mathrm{m}^{3}$ vízmennyiség többlettározásával) történő megemelésével valósult meg. Ezzel a beavatkozással - tartós vízhiányos időszakokban - mérsékelni lehet a szélsőségesen alacsony vízállások kialakulását. A szélsőségesen nedves időszakokban - másik megoldásként - a tóban képződő, szabályozási szint feletti vízkészlet gyors és károkozás nélküli levezetésére van szükség. Ennek érdekében a közelmúltban elkészült a vízlevezető rendszer (Sió-zsilip és Sió-meder) korszerűsítésének szakmai megalapozása és előkészítése. A szükséges kivitelezési munkák végrehajtása megkezdődött.

Mindezekkel párhuzamosan ezen célkitüzések eléréséhez a továbbiakban is szükség van a döntéseket előkészítő folyamatok folyamatos figyelemmel kísérésére, valamint szükséges újraindítani azokat a tudományos igényű és megalapozottságú kutatási programokat, amelyek a vízháztartási folyamatok pontosabb és megbízhatóbb értékelését és - tekintettel az éghajlatváltozásra - elörejelzését szolgálják.

\section{Irodalom}

BARANyi S. (szerk. 1980): A Balaton kutatása és szabályozása. - VITUKI Közlemények 27. Budapest. pp. 227-252., 311-333.

Bendefy L. (1968): A Balaton vízszintjének változásai a neolitikumtól napjainkig. - Hidrológiai Közlöny 48. 6. pp. 257-263.

KravinszkajA G. (szerk. 2019): KDT VIZIG (1993...2019): A Balaton vízháztartási mérlegei. Témajelentés, Siófok.

Kutics K. (szerk. 2015): A Balaton vízgyűjtő területének átfogó hidrológiai vizsgálata, különös tekintettel a lefolyási viszonyok drasztikus változására és a hozzáfolyás csökkenésére. - Tervtanulmány. K+F Consulting Kft., Veszprém. pp. 33-49.

Mészáros E. - Schweitzer F. (szerk. 2002): Föld, víz levegő. Magyar Tudománytár 1. kötet. - Kossuth Kiadó, Budapest. pp. 229-234.

PÁlfai I. (2004): Belvizek és aszályok Magyarországon. Hidrológiai tanulmányok. - Közlekedési Dokumentációs Kft. pp. 381-388.

SzLávik L. (szerk. 2005): A Balaton. - Vízügyi Közlemények különszám, Budapest. pp. 93-104.

VARGA Gy. - JAKUS Á. - KravinszKaJA G. (2019): A közelmúltban előfordult hidrometeorológiai szélsőségek hatása a Balaton vízjárására. - Hidrológiai Közlöny 99. 2. pp. 1-13.

VirÁg Á. (1997): A Balaton múltja és jelene. - Egri Nyomda Kft. pp. 198-277.

VIrÁG Á. (2005): A Sió és a Balaton közös története (1055-2005). - Közlekedési és Dokumentációs Kft. Budapest. pp. 415-422. 